\title{
IMPLEMENTATION OF THE NETWORK STATION SYSTEM ON TVRI BALI
}

\author{
I Nengah Muliarta \\ Universitas Mahendradatta Denpasar, Bali, Indonesia \\ E-mail : nengahmuliarta@gmail.com
}

\begin{abstract}
The democratization of broadcasting in Indonesia is manifested in the implementation of the Network Station System (Sistem Stasiun Jaringan / SSJ) by striving for diversity of ownership and broadcast content in broadcasting institutions. SSJ is also an effort to decentralize broadcasting so that people in the regions get information related to their own regions through subsidiary networks or local broadcasting institutions. TVRI is the only public broadcasting institution that has network subsidiaries throughout Indonesia. This research uses a case study approach, an approach to intensively examine a case with a focus on TVRI Bali. Data collection used interview and observation methods. Data analysis using the Interactive Analysis approach. The results showed that TVRI Bali has not been able to fully implement SSJ. TVRI Bali can only meet the provisions of local broadcast content with a percentage of up to $20 \%$, but has not been able to fulfill the spirit of diversity of ownership according to the basic concept of SSJ. In addition, the principle of diversity of ownership has not been fulfilled due to inconsistencies between the Broadcasting Law and Government Regulation Number 13/2005 and Ministerial Regulation 43/2009 which specifically regulates private television broadcasting institutions.
\end{abstract}

Keywords: SSJ, subnetwork, and TVRI Bali

\begin{abstract}
ABSTRAK
Demokratisasi penyiaran di Indonesia diwujudkan dalam implementasi Sistem Stasiun Jaringan (SSJ) dengan mengupayakan keragaman kepemilikan dan konten siaran di lembaga penyiaran. SSJ juga menjadi upaya desentralisasi penyiaran agar masyarakat di daerah mendapatkan informasi terkait daerahnya sendiri melalui anak jaringan atau lembaga penyiaran lokal. TVRI menjadi satu-satunya lembaga penyiaran publik yang memiliki anak jaringan hampir di seluruh Indonesia. Penelitian ini menggunakan pendekatan studi kasus, sebuah pendekatan untuk menelaah satu kasus secara intensif dengan fokus pada TVRI Bali. Pengumpulan data memakai metode wawancara dan observasi. Analisis data menggunakan pendekatan Analisis Interaktif. Hasil penelitian menunjukkan bahwa TVRI Bali belum mampu menerapkan SSJ secara penuh. TVRI Bali hanya dapat memenuhi ketentuan konten siaran lokal dengan persentasi mencapai $20 \%$, tetapi belum mampu memenuhi semangat keberagaman kepemilikan sesuai dengan konsep dasar SSJ. Selain itu, belum terpenuhinya ketentuan prinsip keberagaman kepemilikan karena ketidaksesuaian aturan antara Undang-Undang Penyiaran dengan PP No.13 / 2005 serta Permen 43 / 2009 yang hanya khusus mengatur lembaga penyiaran televisi swasta.
\end{abstract}

Kata kunci: SSJ, Anak Jaringan, dan TVRI Bali

\section{PENDAHULUAN}

Desentralisasi penyiaran menjadi kebijakan yang diimplementasikan dalam bentuk Sistem Stasiun Berjaringan 


\section{CAPTURE}

(SSJ). Kebijakan implementasi SSJ telah tertuang dengan jelas dalam UndangUndang Republik Indonesia Nomor 32 Tahun 2002. Pasal 6 ayat (1) UndangUndang Penyiaran menyebutkan bahwa penyiaran diselenggarakan dalam satu sistem penyiaran nasional. Kemudian, ayat (3) menyatakan bahwa dalam sistem penyiaran nasional terdapat lembaga penyiaran dan pola jaringan yang adil dan terpadu yang dikembangkan dengan membentuk stasiun jaringan dan stasiun lokal. Selain itu, dipertegas kembali dalam pasal 31 ayat (1) yang menyebutkan bahwa lembaga penyiaran yang menyelenggarakan jasa penyiaran radio atau jasa penyiaran televisi terdiri atas stasiun penyiaran jaringan dan/atau stasiun penyiaran lokal. Pasal 31 ayat (2) menyebutkan bahwa lembaga penyiaran publik dapat menyelenggarakan siaran dengan sistem stasiun jaringan yang menjangkau seluruh wilayah Negara Republik Indonesia. Ketentuan tersebut tampak bahwa tidak lagi ada istilah lembaga penyiaran yang bersiaran secara nasional.

Implementasi regulasi tersebut di atas perlu dilakukan pencermatan pada pelaksanaannya. Peneliti memilih studi kasus pada LPP TVRI Stasiun Bali. TVRI Bali menempatkan kearifan lokal menjadi kekuatan dalam menarik animo pemirsa. Selain itu, Kepala LPP TVRI Stasiun Bali, Sifak, memproyeksikan TVRI Bali menjadi stasiun pembangun untuk masa depan Bali dan juga bangsa Indonesia (Ama, 2018). TVRI Bali menarik diteliti, karena apabila dibandingkan dengan saluran lokal lainnya, TVRI menempati posisi yang sama dengan BaliTV yaitu sama-sama 3,5 persen responden mengatakan sebagai pilihan pertama mereka. Sedangkan, DewataTV hanya 1 persen yang mengatakan DewataTV adalah pilihan (favorit) mereka. Hal ini membuktikan bahwa TVRI Bali tetap menjadi pilihan pertama pemirsa televisi di Bali dibandingkan televisi lokal lainnya (Amanda Gelgel, Dewi Pascarani, Sugiarica Joni, Cahyani, \& Pradipta, 2014). Pembahasan TVRI Bali fokus mengenai permasalahan berikut: 1) apakah seluruh kebijakan SSJ telah terimplementasi secara baik?; 2) apakah TVRI sebagai lembaga penyiaran publik mampu mengimplementasikan ketentuan SSJ?

\section{TINJAUAN PUSTAKA}

Sebelumnya sistem sentralistis hanya menguntungkan lembaga penyiaran nasional yang berada di Jakarta, karena secara ekonomi belanja iklan yang berjumlah lebih dari dua puluh triliun rupiah tersebut dapat dikuasai sepenuhnya di Jakarta. Dengan sistem desentralisasi, stasiun-stasiun Jakarta harus mendirikan stasiun televisi di setiap daerah atau mencari mitra stasiun televisi lokal yang bersedia menjadi bagian dari jaringan (Budiman, 2012). Kebijakan sistem siaran 
berjaringan telah dirumuskan dalam kebijakan dan sudah seharusnya dilaksanakan oleh lembaga penyiaran (Primasanti, 2009). Perbedaan sistem penyiaran berjaringan dengan sistem penyiaran sentralistis adalah kewenangan masyarakat untuk memilih. Di dalam sistem sentralistis, stasiun Jakarta akan mengirimkan dan memaksakan masyarakat di luar Jakarta dengan isi siaran yang sepenuhnya didikte dari Jakarta. Di dalam sistem penyiaran berjaringan, masyarakat bisa meminta stasiun televisi menampilkan materi sesuai kebutuhan setempat serta menolak kalau ada siaran yang bertentangan dengan budaya setempat (Budiman, 2012). Sistem stasiun jaringan merupakan upaya menciptakan keragaman informasi media massa selayaknya merefleksikan struktur dan isinya sesuai dengan keragaman realitas sosial, ekonomi, dan budaya (Aminudin, 2016).

Sistem televisi berjaringan menawarkan jalan keluar yang saling menguntungkan. Idealnya, stasiun-stasiun televisi lokal tak perlu menjadi stasiunstasiun independen yang membiayai diri sendiri. Sebagaimana di banyak negara maju, stasiun-stasiun televisi lokal berposisi sebagai stasiun televisi afiliasi jaringan nasional (Budiman, 2012). Sistem stasiun jaringan hadir dengan cita-cita terwujudnya demokratisasi penyiaran melalui keberagaman isi (diversity of content) dan keberagaman kepemilikan (diversity of ownership). Implementasi regulasi ini diharapkan mampu mendorong industri penyiaran di daerah agar lebih maju dan kebutuhan masyarakat akan informasi yang berimbang dapat terpenuhi (Budiman, 2012 ; Uleng \& Mau, 2016). Kehadiran stasiun televisi lokal menurut Jimmy Silalahi (dalam Amelia \& Sugihartono, 2011) diakui sangat berpengaruh terkait keinginan masyarakat untuk mendapatkan informasi dan progam dari daerahnya sendiri secara optimal.

Masyarakat setiap daerah memerlukan kehadiran stasiun televisi di daerahnya masing-masing yang dapat melayani kebutuhan informasi masyarakat setempat dan memberikan sumbangan yang berarti baik secara politik, sosial budaya, maupun ekonomi (Budiman, 2012). Kehadiran TV lokal memberikan kemungkinan bagi rumah-rumah produksi (production house) yang ada untuk memasok program-program televisi, juga mendorong pertumbuhan rumah-rumah produksi baru di tiap kota/kabupaten, suatu peluang untuk membuka usaha baru dan lapangan kerja baru (Sugihartono, 2009).

Sebelumnya, sejak reformasi 1998 , struktur yang terdapat dalam ranah penyiaran di Indonesia, termasuk sistem kepemilikan media, lebih mencerminkan kekuasaan modal yang terus berupaya meningkatkan keuntungan setinggitingginya melalui penguasaan beberapa stasiun televisi dan juga media lain 


\section{CAPTURE}

(Nursatyo, 2016).

Aturan teknis terkait SSJ dituangkan dalam Peraturan Menteri Komunikasi dan Informatika Republik Indonesia Nomor 43 / PER / M.KOMINFO / 10 / 2009 tentang Penyelenggaraan Penyiaran melalui Sistem Stasiun Jaringan oleh Lembaga Penyiaran Swasta Jasa Penyiaran Televisi. Di dalam Peraturan Menteri 43 Tahun 2009 disebutkan bahwa pelaksanaan sistem stasiun jaringan sebagai arah dalam penerapan kebijakan penyelenggaraan penyiaran pada dasarnya harus mempertimbangkan perkembangan teknologi penyiaran, kecenderungan permintaan pasar, ekonomi, sosial, budaya, dan kondisi lingkungan serta yang terpenting adalah terjaminnya masyarakat untuk memperoleh informasi. Selain itu, disebutkan juga bahwa penyiaran diselenggarakan dalam suatu sistem penyiaran nasional yang memiliki prinsip dasar keberagaman kepemilikan dan program siaran dengan pola jaringan yang adil dan terpadu dalam rangka pemberdayaan masyarakat daerah.

TVRI sebagai lembaga penyiaran merupakan bagian dari penyiaran nasional dan merupakan lembaga penyiaran publik. Peraturan Pemerintah (PP) Nomor 13 Tahun 2005 Tentang Lembaga Penyiaran Publik Televisi Republik Indonesia, khususnya pasal 1 ayat (3) menyebutkan bahwa Lembaga Penyiaran Publik Televisi Republik Indonesia adalah Lembaga
Penyiaran Publik yang menyelenggarakan kegiatan penyiaran televisi, bersifat independen, netral, tidak komersial, dan berfungsi memberikan layanan untuk kepentingan masyarakat. Kemudian, pasal 4 menyebutkan bahwa TVRI mempunyai tugas memberikan pelayanan informasi, pendidikan, hiburan yang sehat, kontrol dan perekat sosial, serta melestarikan budaya bangsa untuk kepentingan seluruh lapisan masyarakat melalui penyelenggaraan penyiaran televisi yang menjangkau seluruh wilayah Negara Kesatuan Republik Indonesia.

\section{METODE}

Penelitian ini menggunakan pendekatan studi kasus yang merupakan suatu pendekatan yang menelaah satu kasus secara intensif, mendalam, mendetail dan komprehensif. Pendekatan studi kasus bertujuan untuk dapat mengungkapkan fenomena sosial, dan dengan studi kasus menguntungkan peneliti, karena dapat mengumpulkan data yang lengkap dan mendalam. Penelitian ini fokus pada kajian terhadap implementasi SSJ oleh TVRI Bali, baik ditinjau dari segi keberagaman ataupun keberagaman isi siaran atau koten siaran.

Penelitian dilakukan dengan menggunakan data hasil evaluasi siaran lokal dan kebijakan manajemen TVRI Bali selama bulan April hingga Mei 2019. Data primer dalam penelitian ini diperoleh dari hasil wawancara dengan narasumber dan 
observasi terhadap program siaran lokal TVRI Bali. Wawancara dilakukan dengan Kepala Bagian Program TVRI Bali dan Komisioner KPID Bali. Data sekunder diperoleh melalui studi literatur terkait sistem stasiun jaringan.

Analisis data menggunakan pendekatan Analisis Interaktif. Data hasil observasi dan wawancara dianalisis secara deskriptif dan diperbandingkan dengan regulasi yang terkait dengan SSJ. Regulasi tersebut di antaranya adalah UndangUndang Penyiaran, Peraturan Komisi Penyiaran Indonesia Nomor 01/P/KPI/03/2012 tentang Pedoman Perilaku Penyiaran (P3) dan Peraturan Komisi Penyiaran Indonesia Nomor 02/P/KPI/03/2012 tentang Standar Program Siaran (SPS), serta Peraturan Menteri Komunikasi dan Informatika Republik Indonesia Nomor 43/PER/M.KOMINFO/ 10/2009. Hasil analisis disajikan secara deskriptif dan disertai dengan gambar pendukung.

\section{PEMBAHASAN}

\subsection{Pola Stasiun Televisi Berjaringan}

Pembahasan pola siaran televisi berjaringan perlu memperhatikan UU Penyiaran. Pasal 6 ayat (3) UndangUndang Penyiaran menyatakan bahwa dalam sistem penyiaran nasional terdapat lembaga penyiaran dan pola jaringan yang adil dan terpadu yang dikembangkan dengan membentuk stasiun jaringan dan stasiun lokal. Kemudian, dipertegas kembali dalam pasal 31 ayat (1) yang menyebutkan bahwa lembaga penyiaran yang menyelenggarakan jasa penyiaran radio atau jasa penyiaran televisi terdiri atas stasiun penyiaran jaringan dan/atau stasiun penyiaran lokal. Dengan memperhatikan pasal 6 dan 31 di atas, kemudian mencermati perkembangan implementasi sistem siaran jaringan di Indonesia, maka dapat dirumuskan tiga pola yaitu pola memecah, pola mengumpul, dan pola perpaduan memecahmengumpul. Pola memecah yaitu pola jaringan yang dibentuk oleh lembaga penyiaran yang sebelumnya bersiaran secara nasional yang kemudian menjadikan strasiun transmisi atau biro di daerah sebagai lembaga penyiaran yang berdiri sendiri, namun tetap menjadi bagian dalam bentuk anak jaringan. Apabila dibuat dalam sebuah diagram, maka pola memecah dapat digambarkan seperti Bagan 1.

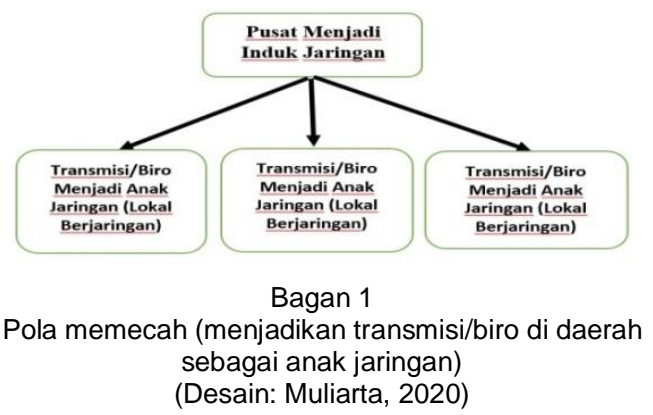

Pola memecah umum diimplementasikan oleh lembaga penyiaran yang sebelumnya bersiaran secara nasional. Permasalahannya kemudian, dalam mengimplementasikan pola memecah tidak 


\section{CAPTURE}

diikuti dengan pelepasan sebagian saham kepada pengusaha lokal yang tertarik untuk berbisnis di industri penyiaran. Pelepasan sebagian saham ini menjadi penting agar keberagaman kepemilikan dalam implementasi SSJ dapat terpenuhi, sehingga tidak terjadi dominasi kepemilikan oleh beberapa orang.

Pola berikutnya adalah pola mengumpul, di mana pola ini merupakan pola SSJ dengan mengumpulkan lembaga penyiaran lokal untuk menjadi anak jaringan atau mengubah status lembaga penyiaran lokal murni yang ada di daerah menjadi lokal berjaringan (anak jaringan). Diagram pola mengumpul ini jika dibuat dalam bentuk diagram dapat digambarkan seperti pada Bagan 2.

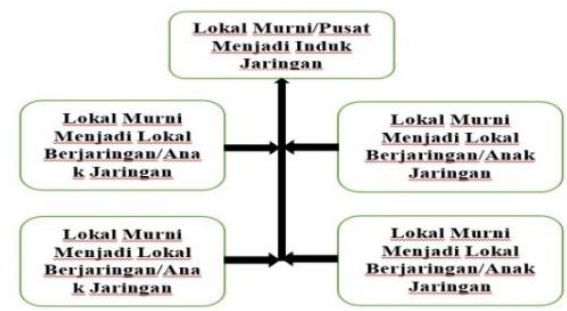

Bagan 2

Pola mengumpul (menjadikan lokal murni di daerah sebagai anak jaringan) (Desain: Muliarta, 2020)

Pola mengumpul cenderung dilakukan oleh lembaga penyiaran yang memiliki target untuk memperluas jangkauan siaran, sehingga mengumpulkan atau membentuk anak jaringan di daerah-daerah. Permasalahannya dalam pola mengumpul ini adalah lembaga penyiaran induk sering mengakuisisi anak jaringan, sehingga keragaman kepemilikan tidak terjadi dan program siaran anak jaringan sangat ditentukan oleh induk jaringan.

Terakhir, pola memecah-mengumpul yaitu pola implementasi SSJ dengan menjadikan transmisi/biro di daerah menjadi anak jaringan atau lembaga penyiaran lokal berjaringan dan juga mengumpulkan atau menjadikan lembaga penyiaran lokal murni menjadi anak jaringan. Permasalahan yang terjadi hampir sama dengan pola mengumpul, di mana induk jaringan cenderung mengakuisisi anak jaringan. Pola memecah-mengumpul ini apabila digambarkan menjadi seperti Bagan 3.

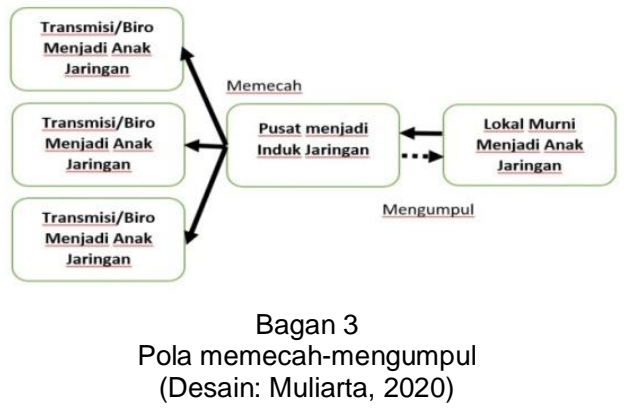

Pola mengumpul dan pola memecahmengumpul sama-sama terdapat kecenderungan akuisisi oleh induk jaringan. Hal ini sejalan dengan pandangan Budiman (2012) yang menyatakan sistem televisi berjaringan, pada dasarnya memiliki kelemahan, karena membuka celah bagi stasiun televisi nasional, untuk membeli mayoritas saham televisi lokal. Menurut aturan, durasi relai memang harus didominasi oleh konten lokal. Tetapi, ketika saham mayoritas dibeli oleh televisi nasional, maka konten lokal sulit 
dipertahankan. Berbeda halnya dengan Nursatyo (2016) yang berpendapat bahwa celah dalam regulasi telah dijadikan strategi bisnis oleh industri media di Indonesia untuk menguasai lebih dari satu stasiun televisi, yaitu dengan cara menguasai saham perusahaan induk (holding company) yang memiliki perusahaan media televisi.

Penulis mencermati lembaga penyiaran publik TVRI dalam hal implementasi SSJ, menurut penulis, pada dasarnya TVRI dapat menerapkan pola memecah, mengingat TVRI telah memiliki biro atau stasiun hampir di seluruh daerah di Indonesia. Namun, kenyataannya bahwa keberadaan TVRI di daerah masih berstatus biro dengan pimpinan kepala stasiun, seperti hanya Kepala TVRI Stasiun Bali dan bukan setingkat Kepala Lembaga Penyiaran Publik. Hal ini menjadi bukti bahwa manajemen dan kebijakan di TVRI Bali ditentukan oleh TVRI Pusat Jakarta. Wawancara dengan Kepala Pengembangan Program dan Pengembangan Usaha TVRI Bali, Juremi Wijaya, diakuinya bahwa kebijakan TVRI Bali ditentukan oleh TVRI Pusat. Begitu juga dengan anggaran dan kepegawaian ditentukan oleh TVRI Pusat (Wijaya, 2019). Apabila kemudian dihubungkan dengan konsep keragaman kepemilikan, maka tidak akan dapat terpenuhi, karena akan berbenturan dengan ketentuan pasal 33 ayat (1) Peraturan Pemerintah Republik
Indonesia Nomor 13 Tahun 2005 Tentang Lembaga Penyiaran Publik Televisi Republik Indonesia. Pasal 33 ayat (1) menyebutkan bahwa kekayaan TVRI merupakan kekayaan negara yang tidak dipisahkan, yang dikelola sendiri sesuai dengan ketentuan peraturan perundangundangan yang berlaku dan dimanfaatkan untuk mendanai kegiatan operasionalnya.

Sentralnya peran pusat dalam manajemen dan kebijakan di TVRI, hampir mirip dengan yang terjadi di lembaga penyiaran swasta, misalnya Kompas TV Dewata. Perencanaan di Kompas TV Dewata bersifat top-down atau satu arah, di mana tidak terdapat komunikasi dan keterlibatan Kompas TV Dewata dalam menentukan kebijakan dan aturan-aturan yang ditetapkan oleh Kompas TV pusat. Adanya kebijakan pembatasan jumlah karyawan yang ditetapkan oleh Kompas TV pusat membuat Kompas TV Dewata mengalami kesulitan dalam melakukan pengorganisasian terutama dalam hal pembagian fungsi dan tugas untuk masingmasing divisi maupun karyawan (Arsani et al., 2017). Selain itu, kendali iklan masih berpusat di Jakarta dan dikuasai induk jaringan.

Apabila hal itu terus berlangsung, maka kondisi yang sulit akan tetap menimpa televisi-televisi lokal. Pilihannya hanya terpinggir dan kalah, atau menyerahkan diri kepada pemilik modal yang sudah mapan dari Jakarta. Persoalan 
ini dapat menjadi berbahaya, karena yang akan muncul adalah keseragaman, demokratisasi tidak berjalan, dan publik lokal tetap hanya akan menjadi objek siaran (Aminudin, 2016).

\subsection{Celah dalam Regulasi}

Hal yang cukup menarik dalam implementasi SSJ adalah terkait sinergitas antara satu aturan dengan aturan lainnya. Di dalam Undang-Undang Penyiaran pasal 6 ayat (3) dinyatakan bahwa dalam sistem penyiaran nasional terdapat lembaga penyiaran dan pola jaringan yang adil dan terpadu yang dikembangkan dengan membentuk stasiun jaringan dan stasiun lokal. Kemudian, dalam PP Nomor 13 Tahun 2005 Tentang Lembaga Penyiaran Publik Televisi Republik Indonesia, khususnya pasal 12 ayat (4) disebutkan stasiun penyiaran dapat menyelenggarakan siaran dengan sistem stasiun jaringan yang menjangkau seluruh wilayah Negara Kesatuan Republik Indonesia. Namun, dalam Peraturan Menteri Kominfo Nomor 43 Tahun 2009 hanya dibatasi pada lembaga penyiaran swasta, terbukti dari judul peraturan tersebut yaitu Penyelenggaraan Penyiaran melalui Sistem Stasiun Jaringan oleh Lembaga Penyiaran Swasta Jasa Penyiaran Televisi. Nursatyo (2016) menemukan adanya celah yang memungkinkan sulitnya mewujudkan keberagaman kepemilihan dalam penerapan SSJ.
Pada dasarnya Undang-Undang Penyiaran memiliki semangat melarang konsentrasi kepemilikan apalagi monopoli kepemilikan media penyiaran, namun celah-celah dalam peraturan yang ragu seperti frase "dibatasi" dan "badan hukum" dalam pasal 18 ayat (1) dan "pihak lain" dalam pasal 34 ayat (4) memberikan peluang bagi kalangan industri televisi besar untuk menguasai beberapa stasiun televisi dengan cara membeli saham pada level perusahaan induk. Pendapat Gilang Gusti Aji (2014) dikatakan bahwa apabila ditinjau dari sisi pelaksanaan regulasi, pendirian jaringan di daerah tidak kemudian dilakukan untuk memecah kepemilikan seperti yang diamanatkan Undang-Undang Penyiaran lewat konsep diversity of ownership, namun lebih kepada pola konsolidasi administrasi untuk menghadapi ketentuan undang-undang. Proses ini ibarat sebuah demokratisasi semu. Justru yang terjadi adalah pemusatan kepemilikan yang kemudian akan membahayakan demokrasi itu sendiri.

\subsection{Konten Lokal TVRI Bali}

Selama ini TVRI Bali memancarkan siarannya secara keseluruhan selama 20 jam dengan siaran lokal mencapai 4 jam. Apabila dipersentasekan, maka persentase siaran lokal TVRI Bali sebesar 20\% atau lebih tinggi dari batas minimum yang dipersyaratkan. Peraturan Menteri Kominfo Nomor 43 Tahun 2009 pasal 8 ayat (3) 
menyebutkan bahwa dalam sistem stasiun jaringan, setiap stasiun penyiaran lokal harus memuat siaran lokal dengan durasi paling sedikit 10\% (sepuluh per seratus) dari seluruh waktu siaran per hari. Kemudian, dalam ayat (4) disebutkan berdasarkan perkembangan kemampuan daerah dan lembaga penyiaran swasta keharusan memuat siaran lokal sebagaimana dimaksud pada ayat (3) secara bertahap naik menjadi paling sedikit $50 \%$ (lima puluh per seratus) dari seluruh waktu siaran per hari. Standar Program Siaran (SPS) pasal 68 ayat (1) menyebutkan program siaran lokal wajib diproduksi dan ditayangkan dengan durasi paling sedikit $10 \%$ (sepuluh per seratus) untuk televisi dan paling sedikit $60 \%$ (enam puluh per seratus) untuk radio dari seluruh waktu siaran berjaringan per hari. Sedangkan, pada ayat (3) disebutkan bahwa program siaran lokal sebagaimana yang dimaksud pada ayat (1) secara bertahap wajib ditingkatkan hingga paling sedikit 50\% untuk televisi dari seluruh waktu siaran berjaringan per hari. Namun, aturan ini tidak menyebutkan batas waktu untuk mencapai muatan siaran lokal sebanyak $50 \%$.

Sebuah penelitian di Yogyakarta pada tahun 2015 menunjukkan bahwa terdapat 11 stasiun televisi belum menayangkan program lokal dengan durasi minimal 10 persen dari waktu bersiaran per hari (Supadiyanto, 2015). Kompas TV
Dewata hanya mampu memenuhi batas minimal penayangan siaran lokal, yaitu hanya sebesar $10 \%$ dari jumlah waktu siaran setiap harinya (Arsani et al., 2017). RCTI Network Banten belum bisa mengimplementasikan isi siaran lokal minimal $10 \%$ karena terkendala teknis yang dialami seperti keterbatasan SDM dan muatan lokal (Aminudin, 2016). KompasTV Lampung juga belum mampu menjalankan beberapa poin dari peraturan, seperti mengenai jam tayang, penambahan persentase durasi tayangan program lokal dan juga penggunaan sumber daya manusia lokal yang masih minim (Arfad, 2018). Sedangkan, televisi lokal di Batam, selain menghadapi kendala finansial dan sumber daya manusia, ditambah pula dengan belum adanya atau tidak adanya peratuan daerah yang secara eksplisit mendukung tentang tumbuh kembangnya televisi lokal di Batam, sehingga secara tidak langsung berdampak pada perkembangan televisi lokal terutama dalam mengusung kepentingan publik yang berbasis kearifan lokal secara maksimal (Aminudin, 2016).

Pada kenyataannya, masalah yang dihadapi televisi lokal saat ini antara lain persaingan antar lembaga penyiaran, sumber daya manusia serta infrastruktur yang kurang memadai menjadikan televisi lokal mengalami banyak hambatan dalam proses produksi konten lokal (Juditha, 2015). Sisi yang lain adalah prioritas 
mengejar keuntungan dari lembaga penyiaran juga menjadi ancaman bagi terciptanya keragaman isi televisi (Hendrawan, 2013). Supadiyanto (2015) mengatakan bahwa minimnya program siaran lokal seharusnya menjadi peluang emas bagi kampus komunikasi, rumah produksi, serta pihak lainnya untuk memproduksi program lokal dengan menjalin kerjasama dengan lembaga penyiaran.

Sebelumnya, TVRI Bali menayangkan siaran lokal dari pukul 15.00-19.00 WITA, namun sejak bulan April 2019 siaran lokal diubah yaitu dari pukul 09.00-11.00 WITA dan 17.00-19.00 WITA. Perubahan waktu siaran muatan lokal ini didasarkan pada hasil survei secara nasional bahwa waktu prime time berada pada rentang pukul 09.00-11.00 WITA dan 17.00-19.00 WITA. Upaya ini menjadi sejalan dengan aturan yang tertuang dalam Standar Program Siaran (SPS) pasal 68 ayat (2) yang menyebutkan bahwa program siaran lokal disiarkan paling sedikit 30\% di antaranya wajib ditayangkan pada waktu prime time waktu setempat. Hal ini cukup berbeda dengan Kompas TV Dewata yang menayangkan siaran muatan lokal pada pagi hari pukul 05.30 hingga 08.00 WITA (Arsani et al., 2017).

Beberapa program siaran muatan lokal yang dikembangkan oleh TVRI Bali di antaranya adalah Gatra Bali, Balivision, Swara, Bali Hari Ini, Jendela Bali, Manacika
Power, Gelar Ide \& Kreasi, Wirasa, Siraman Rohani, Tetaring dan Yastra Bali. Gatra Bali merupakan sebuah program berita yang ditayangkan setiap hari dengan menggunakan bahasa Bali. Balivision merupakan sebuah program berita yang menggunakan bahasa Inggris. Yastra Bali adalah sebuah program siaran tentang belajar bahasa dan menulis Bali. Program hiburan lainnya yaitu Dedalu, sebuah program yang menampilkan lagu-lagu pop Bali. Program-program siaran tersebut mengangkat tentang hal-hal yang terjadi di Bali, dan diproduksi dengan melibatkan tenaga sumber daya manusia yang ada di TVRI Bali, dan disiarkan di wilayah Bali. Hal ini sesuai dengan ketentuan pada Pedoman Prilaku Penyiaran (P3) pasal 1 ayat (15) yang menyebutkan bahwa program lokal adalah program siaran dengan muatan lokal yang mencakup program siaran jurnalistik, program siaran faktual, dan program siaran non faktual dalam rangka pengembangan potensi daerah setempat serta dikerjakan dan diproduksi oleh sumber daya dan lembaga penyiaran daerah setempat.

Pasal 1 ayat (8) Pedoman Perilaku Penyiaran (P3) menyebutkan bahwa sistem stasiun jaringan adalah tata kerja yang mengatur relai siaran secara tetap antar lembaga penyiaran. Definisi ini juga mempertegas bahwa tidak lagi ada stasiun yang bersiaran secara nasional, justru yang ada adalah anak jaringan dan induk 
jaringan. Kenyataan di lapangan menunjukkan transisi siaran dari anak jaringan ke induk jaringan masih menggunakan istilah "bergabung dengan siaran nasional" dan bukan "bergabung ke induk jaringan". Hal ini juga terjadi pada TVRI Bali, seperti yang disajikan dalam Gambar 1.
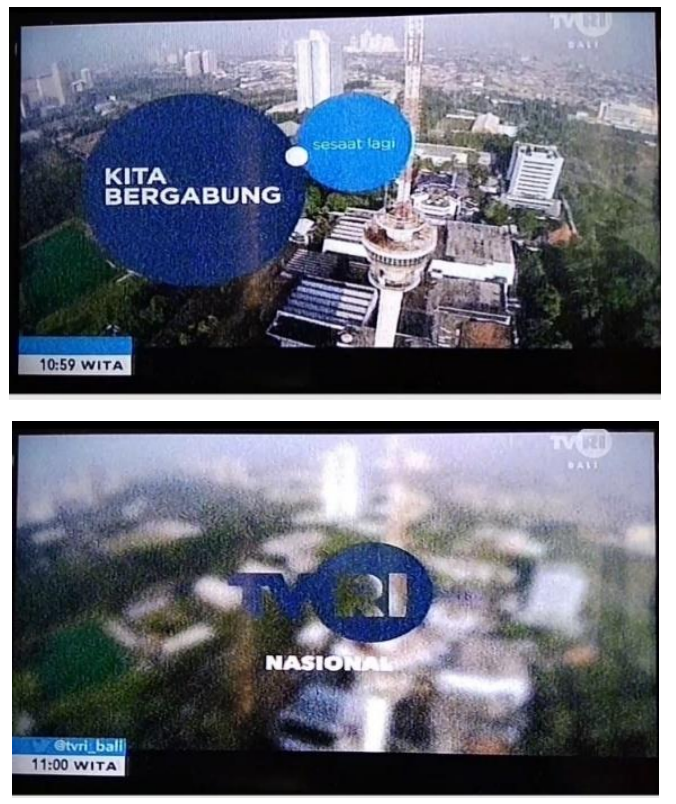

Gambar 1

TVRI Bali masih menggunakan istilah "Sesaat Lagi Kita Bergabung-TVRI Nasional".

(Sumber: Cuplikan layar TVRI Bali, 2020)

Kondisi ini menjadi bukti bahwa SSJ belum terimplementasi secara penuh, SSJ masih terimplementasi sebatas bentuk siaran muatan lokal dan konsep SSJ belum dipahami secara menyeluruh. Keadaan ini sejalan dengan pandangan (Aminudin, 2016) yang menyatakan bahwa para pengelola televisi dari Jakarta beranggapan, bila SSJ didesain untuk memberikan variasi siaran bagi masyarakat daerah, maka mereka merasa sudah melakukannya selama ini, misalnya melalui acara berita ataupun siaran yang bertemakan daerah. Sementara itu, KPID memandang kriteria konten lokal berarti sepenuhnya berasal dari daerah dan didistribusikan sepenuhnya untuk daerah. Berbeda dengan Primasanti (2009) yang menduga ada kepentingan-kepentingan terselubung yang masih menghendaki keberadaan televisi yang bersiaran secara nasional.

Indonesia harus segera menciptakan kondisi ekonomi politik yang stabil untuk menjamin berlangsungnya penerapan sistem stasiun berjaringan. Arsani et al. (2017) mengatakan bahwa belum berjalannya SSJ tidak terlepas dari adanya dominasi kekuasaan oleh pusat (stasiun induk) yang dapat dikatakan kurang sesuai dengan konsep pelaksanaan sistem stasiun jaringan yang bertujuan untuk terwujudnya desentralisasi melalui diversity of ownership dan diversity of content dalam rangka menciptakan keberagaman dan keadilan dalam industri penyiaran di Indonesia, sekaligus memberikan peluang untuk masyarakat dan stasiun penyiaran daerah mengembangkan kemampuannya dalam dunia penyiaran.

\subsection{Pengawasan pada Implementasi SJJ}

Komisioner Komisi Penyiaran Indonesia Daerah (KPID) Bali, Anak Agung Gede Rai Sahadewa, mengakui bahwa KPID Bali belum pernah melakukan 


\section{CAPTURE}

evaluasi terhadap implementasi SSJ terhadap TVRI Bali. KPID Bali lebih fokus pada implementasi SSJ pada lembaga penyiaran swasta, apalagi implementasi SSJ masih bermasalah di lembaga penyiaran swasta (Sahadewa, 2019). Berdasarkan catatan KPID Bali, khusus pada lembaga penyiaran swasta penerapan SSJ dengan konten siaran lokal rata-rata masih $10 \%$, sedangkan pada TVRI Bali sudah di atas $10 \%$. Hasil wawancara ini memberikan gambaran bahwa KPI hanya mensyaratkan implementasi SSJ pada ketentuan pemenuhan konten siaran lokal $10 \%$ dan tidak ada usaha untuk mengarahkan lembaga penyiaran menuju pemenuhan konten siaran lokal hingga 50\%. KPID Bali juga tidak menerapkan kebijakan evalusi SSJ terhadap implementasi keragaman kepemilikan. Hasil ini sejalan dengan pandangan Aminudin (2016) yang menyatakan ketidaktegasan regulator mengawal dan menegakkan implementasi kebijakan sistem stasiun jaringan dapat memunculkan berbagai ketidakadilan. Mulai dari ketidakadilan alokasi frekuensi yang mengutamakan televisi nasional, ketidakadilan struktural bagi televisi lokal dalam persaingan bisnis dengan televisi jaringan nasional, sampai pada ketidakadilan bagi publik lokal, karena tanpa keberagaman, demokratisasi tidak berjalan, dan publik lokal tetap hanya akan menjadi objek siaran semata.
Pendapat Wahyuni, Cangara, \& Nadjib (2014) menyatakan bahwa Komisi Penyiaran Indonesia Daerah (KPID) yang berfungsi sebagai regulator penyelenggaraan penyiaran di Indonesia seharusnya mampu memberikan pengawasan dan evaluasi terhadap stasiun TV lokal di daerah. Sejalan dengan itu, (Arfad, 2018) berharap Komisi Penyiaran Indonesia Daerah (KPID) lebih ketat lagi dalam hal mengawasi televisi-televisi di daerah. Selain itu, juga diperlukan penambahan poin dalam peraturan mengenai modal yang berasal dari lokal agar tidak terlalu terpaku pada pusat. Apabila dicermati ketidaktegasan KPI dalam implementasi SSJ sangat dipengaruhi oleh pemahaman komisioner terhadap konsep dasar SSJ dan keseriusannya, serta rencana aksi yang dipersiapkan dalam penerapan SSJ.

Apabila dicermati TVRI Bali tidak saja mengalami permasalahan dalam implementasi SSJ, karena tidak sinkronnya antara Undang-Undang Penyiaran dengan PP Nomor 13 Tahun 2005 serta Permenkominfo Nomor 43 Tahun 2009, tetapi juga karena tidak sinkronnya proses perizinan dan perpanjangan izin. Perpanjangan izin merupakan kesempatan evaluasi terhadap program dan kebijakan penyiaran dari lembaga penyiaran. Ketentuan pada pasal 34 ayat (1) poin b menyebutkan bahwa izin penyelenggaraan penyiaran televisi diberikan untuk jangka 
waktu 10 tahun, kemudian pada ayat (6) disebutkan izin penyelenggaraan penyiaran dinyatakan berakhir, karena habis masa izin dan tidak diperpanjang kembali. Kenyataan di lapangan menunjukkan bahwa berdasarkan data KPID Bali diketahui jika TVRI Bali belum pernah melakukan proses perpanjangan izin. PP Nomor 13 Tahun 2005 juga tidak menyebutkan ketentuan perpanjangan izin oleh TVRI sebagai sebuah lembaga penyiaran yang menggunakan frekuensi publik dan dana publik melalui APBN. Berbeda dengan PP 50 Tahun 2005 tentang Penyelenggaraan Penyiaran Lembaga Penyiaran Swasta, di mana dalam pasal 8 ayat (1) poin b disebutkan bahwa jangka waktu berlakunya izin penyelenggaraan penyiaran adalah 10 (sepuluh) tahun untuk izin penyelenggaraan penyiaran televisi. Kemudian pada pasal 9 ayat (2) poin b dinyatakan jangka waktu berlakunya perpanjangan izin penyelenggaraan penyiaran adalah 10 (sepuluh) tahun untuk izin penyelenggaraan penyiaran televisi.

Paparan di atas menunjukkan bahwa penerapan SSJ pada TVRI Bali belum dilakukan secara penuh. TVRI Bali hanya dapat memenuhi ketentuan konten siaran lokal dengan persentase mencapai 20\%, dan belum mampu memenuhi semangat keberagaman kepemilikan sesuai dengan konsep dasar SSJ. Padahal keberagaman kepemilikan TVRI di Bali dan daerah lainnya di Indonesia dapat diwujudkan dengan melibatkan pemerintah daerah baik provinsi atau kabupaten. Di sisi lain, harus diakui belum terimplementasinya SSJ pada TVRI Bali salah satunya juga akibat ketidaksesuaian aturan antara UndangUndang Penyiaran dengan PP Nomor 13 Tahun 2005 serta Permenkominfo Nomor 43 Tahun 2009.

Analisis ini sejalan dengan penelitian sejenis di Banten yang menunjukkan bahwa implementasi kebijakan sistem stasiun jaringan di Banten masih sangat jauh dari konteks ideal. Implementasi kebijakan sistem stasiun jaringan yang tidak optimal dapat berimplikasi pada tidak tercapainya prinsip diversity of content dan diversity of ownership, padahal kedua prinsip keberagaman tersebut merupakan dasar yang harus dipegang teguh untuk menciptakan sistem persaingan yang sehat antar lembaga penyiaran, serta mampu memenuhi kepentingan public (Wahyuni et al., 2014 ; Aminudin, 2016).

\section{SIMPULAN}

Pola dalam implementasi SSJ di Indonesia terdapat tiga jenis yaitu pola memecah, pola mengumpul, dan pola perpaduan memecah - mengumpul. Lembaga penyiaran publik TVRI dalam implementasi SSJ, pada dasarnya dapat menerapkan pola memecah, mengingat TVRI telah memiliki biro atau stasiun hampir di seluruh daerah di Indonesia. Penerapan SSJ pada TVRI Bali belum 


\section{CAPTURE}

mampu dilakukan secara penuh. TVRI Bali hanya dapat memenuhi ketentuan konten siaran lokal dengan persentasi mencapai $20 \%$, tetapi belum mampu memenuhi semangat keberagaman kepemilikan sesuai dengan konsep dasar SSJ. Belum idealnya implementasi SSJ sangat dipengaruhi oleh kesiapan dan pemahaman lembaga penyiaran, tidak sinkronnya aturan dan lemahnya pengawasan dari regulator penyiaran.

\section{UCAPAN TERIMA KASIH}

Penulis mengucapkan terima kasih kepada Kepala Pengembangan Program dan Pengembangan Usaha TVRI Bali, Drs. Juremi Wijaya yang telah membantu penulis dalam memberikan informasi terkait kebijakan-kebijakan yang berlaku di TVRI Bali. Ucapan yang sama juga disampaikan kepada Kasi Pengembangan Usaha, TVRI Bali, Sunar Wardoyon yang telah banyak membantu dalam mengumpulkan data rundown acara. Penulis juga mengucapkan terima kasih kepada Komisioner Komisi Penyiaran Indonesia Daerah (KPID) Bali, Anak Agung Gede Rai Sahadewa, yang telah banyak membantu dalam memberikan informasi terkait kebijakan KPID Bali.

\section{DAFTAR ACUAN}

Aji, G. G. (2014). Spasialisasi Media dan Demokratisasi Penyiaran Implementasi Sistem Siaran Televisi Berjaringan di Indonesia. Semiotika, 8(2), 131-.

Ama. (2018). TVRI Bali Go Internasional,
Jadi Daya Tarik Adat dan Pariwisata. Jarrakpos. Retrieved from https://jarrakpos.com/17/07/2018/tv ri-bali-go-internasional-jadi-dayatarik-adat-dan-pariwisata/

Amanda Gelgel, N. M. R., Dewi Pascarani, N. N., Sugiarica Joni, I. D. A., Cahyani, D. Y., \& Pradipta, A. D. (2014). Profil Demografis dan Psikografis Pemirsa Siaran TVRI di Bali [Laporan Penelitian]. Denpasar: Universitas Udayana. Retrieved from Universitas Udayana website: https://simdos.unud.ac.id/uploads/fi le_riwayat_penelitian_1_dir/cad40e 7ē774049d5e24564b4967b8c82.p df

Amelia, C. R., \& Sugihartono, R. A. (2011). Pengaruh Sajian Program Berita TATV terhadap Kebijakan Pemkot Surakarta dalam Memilih Media Publikasi. CAPTURE: Jurnal Seni Media Rekam, 3(1), 28-36. doi: https://doi.org/10.33153/capture.v3i 1.645

Aminudin, A. (2016). Implementasi Regulasi Sistem Stasiun Jaringan (Analisis Ekonomi Politik Media pada RCTI Network Banten). Communication, 7(1), 47-62.

Budiman, A. (2012). Sistem Penyiaran Televisi Berjaringan. Info Singkat: Pemerintahan Dalam Negeri, IV(3). Retrieved from http://berkas.dpr.go.id/puslit/files/inf o_singkat/Info\%20Singkat-IV-3-IP3DI-Februari-2012-20.pdf

Hendrawan, B. (2013). Televisi Lokal: Antara Kepentingan Korporat dan Fungsi Sosial. Jurnal Komunikasi Indonesia, 2(1), 5-14.

Juditha, C. (2015). Televisi Lokal dan Konten Kearifan Lokal (Studi Kasus di Sindo TV Kendari). Jurnal Penelitian Komunikasi Dan Pembangunan, 16(1), 49-64.

Nursatyo. (2016). Dinamika Interaksi Agen 

dan Struktur dalam Mencegah Konsentrasi Kepemilikan Media Televisi. Komuniti: Jurnal Komunikasi Dan Teknologi Informasi, VIII(1), 64-81.

Primasanti, K. B. (2009). Studi Eksplorasi Sistem Siaran Televisi Berjaringan di Indonesia. Scriptura, 3(1), 85102.

Sahadewa, A. A. G. R. (2019). Wawancara Komisioner Komisi Penyiaran Indonesia Daerah (KPID) Bali.

Sugihartono, R. A. (2009). Televisi Lokal sebagai Medium Pencitraan Lokalias Daerah. ACINTYA: Jurnal Penelitian Seni Budaya, 1(1), 1-15. doi:

https://doi.org/10.33153/acy.v1i1.1 7

Supadiyanto. (2015). Implementasi Program Siaran Lokal pada Stasiun Televisi di Daerah Istimewa Yogyakarta. Jurnal AnNida, 7(2), 65-78.

Uleng, A. A. D., \& Mau, M. (2016). Identitas Lokal vs Sentralisasi Udara Radio Berjaringan di Kota Makassar. KAREBA: Jurnal IImu Komunikasi, 5(1), 1-14.

Wahyuni, D., Cangara, H., \& Nadjib, M. (2014). Manajemen dan Kebijakan Operasional Televisi Nasional Berbasis Lokal di Kota Makassar. KAREBA: Jurnal IImu Komunikasi, 3(3), 210-217.

Wijaya, J. (2019). Wawancara Kepala Pengembangan Program dan Pengembangan Usaha TVRI Bali. 